\title{
Fe-Ti-Zr (Iron-Titanium-Zirconium)
}

\section{Raghavan}

The previous review of this system by [1992Rag] was limited to a peritectic type of pseudobinary section between $\mathrm{Fe}_{2} \mathrm{Ti}$ and $\mathrm{Fe}_{2} \mathrm{Zr}$. Recently, [2007Zho] determined a tentative isothermal section at $900{ }^{\circ} \mathrm{C}$ for this system.

\section{Binary Systems}

There are two intermediate phases in the Fe-Ti system: $\mathrm{Fe}_{2} \mathrm{Ti}\left(C 14, \mathrm{MgZn}_{2}\right.$-type hexagonal) and $\mathrm{FeTi}(B 2, \mathrm{CsCl}$-type cubic). According to the $\mathrm{Fe}-\mathrm{Zr}$ phase diagram proposed by [2002Ste], the intermediate phases in the system are: hexagonal $\mathrm{Fe}_{2} \mathrm{Zr}$ (26.5-27.0 at.\% $\mathrm{Zr} ; C 36, \mathrm{MgNi}_{2}$-type hexagonal, stable between 1345 and $1240{ }^{\circ} \mathrm{C}$ ), cubic $\mathrm{Fe}_{2} \mathrm{Zr}$ (27.5-34.4 at.\% $\mathrm{Zr} ; C 15, \mathrm{MgCu}_{2}$-type cubic, stable from $1673{ }^{\circ} \mathrm{C}$ to room temperature), $\mathrm{FeZr}_{2}\left(\mathrm{C} 16, \mathrm{CuAl}_{2}\right.$-type tetragonal, stable between 951 and $780^{\circ} \mathrm{C}$ ), and $\mathrm{FeZr}_{3}$ ( $E 1_{a}$-type orthorhombic, stable below $851^{\circ} \mathrm{C}$ ). The authors concluded that $\mathrm{Fe}_{23} \mathrm{Zr}_{6}$ (or $\mathrm{Fe}_{3} \mathrm{Zr}$ ) is not an equilibrium phase. The Ti-Zr phase diagram [Massalski2] shows that $\beta \mathrm{Ti}-\beta \mathrm{Zr}$ and $\alpha \mathrm{Ti}-\alpha \mathrm{Zr}$ pairs form continuous solid solutions.

\section{Ternary Isothermal Section}

With starting metals of $99.9 \% \mathrm{Fe}, 99.5 \% \mathrm{Ti}$, and $99.9 \% \mathrm{Zr}$, [2007Zho] prepared diffusion triples, which were annealed at $900{ }^{\circ} \mathrm{C}$ for $1440 \mathrm{~h}$ and quenched in water. The phase equilibria were studied with electron probe microanalysis and the compositions of the coexisting phases were listed. No structural analysis was done. The tentative isothermal section at $900{ }^{\circ} \mathrm{C}$ constructed by [2007Zho] is redrawn in Fig. 1 to agree with the accepted binary data. The solubility of $\mathrm{Zr}$ in $\mathrm{Fe}_{2} \mathrm{Ti}$ and $\mathrm{FeTi}$ is 8.1 and 7.2 at.\% respectively. The solubility of $\mathrm{Ti}$ in $\mathrm{Fe}_{2} \mathrm{Zr}$ (cubic) and $\mathrm{FeZr}_{2}$ is 11.3 and 26.9 at.\%, respectively. No ternary compounds were found.

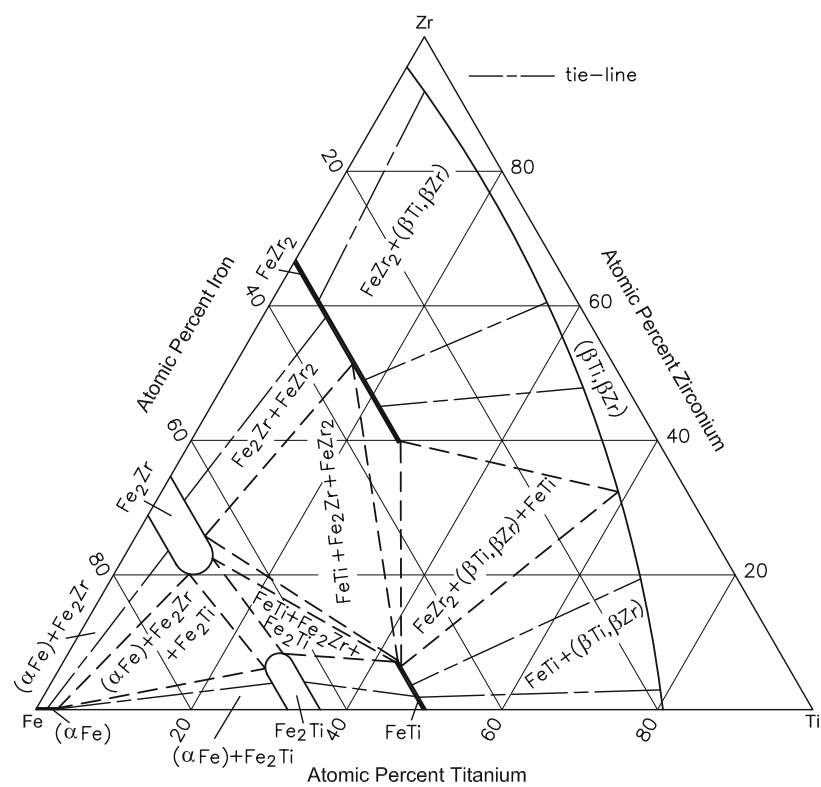

Fig. 1 Fe-Ti-Zr tentative isothermal section at $900{ }^{\circ} \mathrm{C}$ [2007Zho]

\section{References}

1992Rag: V. Raghavan, The Fe-Ti-Zr (Iron-Titanium-Zirconium) System, Phase Diagrams of Ternary Iron Alloys. Part 6B, Indian Institute of Metals, Calcutta, 1992, p 1223-1224

2002Ste: F. Stein, G. Sauthoff, and M. Palm, Experimental Determination of Intermetallic Phases, Phase Equilibria, and Invariant Reaction Temperatures in the Fe-Zr System, J. Phase Equilb., 2002, 23(6), p 480-494

2007Zho: G.J. Zhou, S. Jin, L.B. Liu, H.S. Liu, and J.P. Jin, Determination of Isothermal Section of Fe-Ti-Zr Ternary System at $1173 \mathrm{~K}$, Trans. Nonferrous Met. Soc. China, 2007, 17(5), p 963-966 